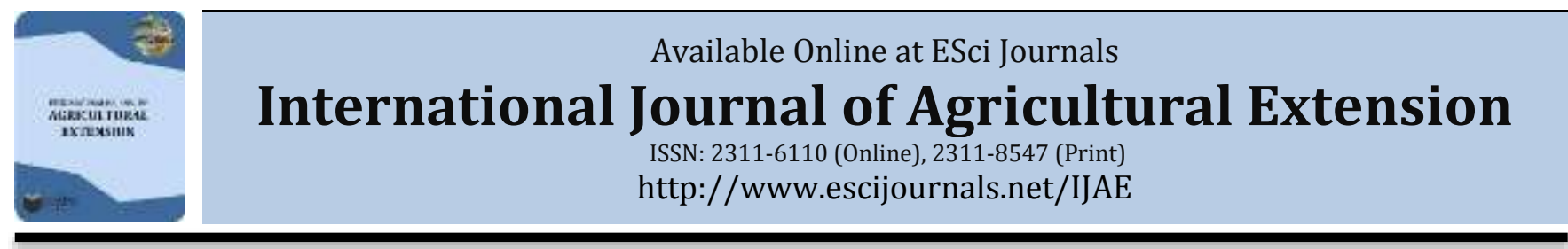

\title{
DEVELOPMENT OF A SCALE TO MEASURE FAMILY FARMING EFFICIENCY OF WOMEN HEADED HOUSEHOLDS
}

\author{
aHarshitha Dharanendra, bMadhu Prasad V. L. \\ ${ }^{a}$ Department of Agricultural Extension, GKVK, University of Agricultural Sciences, Bengaluru, Karnataka, India. \\ ${ }^{b}$ Farmers Training Institute, GKVK, University of Agricultural Sciences, Bengaluru India.
}

\section{A B S T R A C T}

This study sought to develop a scale to measure the family farming efficiency of women-headed households. Likert, Edwards and Paul et al. method were employed to development of the scale. Six relevant dimensions and 154 statements were screened through literature review and discussions with experts. Statements were mailed to 130 judges in the agricultural extension \& other related fields and 60 were received back. Further, the "Relevancy Percentage" "Relevancy weightage" and "Mean Relevancy Score" were worked out. The final scale comprising of six dimensions and 66 statements was standardized for administration. The scale developed was administered to 30 respondents in the non-sample area for measuring family farming efficiency. The results revealed that the reliability coefficient and validity of the scale appeared 0.8925 and 0.94 respectively, which is higher than the standard value (0.70).This certitude the reliability and validity of the developed scale. Thus, the scale can be useful explicitly to measure the family farming efficiency of Women Headed Households.

Keywords: Family Farming Efficiency, Women Headed Households, Reliability and Validity.

\section{INTRODUCTION}

The declaration of 2014 as the International Year of Family Farming by United Nations reflects a growing global consensus that family farming is key to feeding a world population that is expected to reach more than nine billion by 2050. Family farming is a means of organizing all agricultural and allied activities which is managed and operated by a family and is predominantly reliant on family labour, including women, men and children (Jose Graziano Da Silva., 2014). In India, women are a major producer of food because agriculture is a large household enterprise. Further, women end up heading household were often found to be the absence of a resident male head. It was due to widowhood, divorce, separation, desertion, lack of mature sons to take over the households, migration of male member for long periods or loss of economic function by resident males due to disability and illness. The portion of womenheaded households in India is escalating. According to

* Corresponding Author:

Email: harshithadkumar1@gmail.com

(C) 2018 ESci Journals Publishing. All rights reserved. the census 2011, a total of 23 million and 19.65 lakh female-headed households exist in rural India and Karnataka respectively (Anon, 2011). The family farming efficiency of women-headed households depends on the work carried out by women, men and children to get maximum benefit with available resources. Hence, there is a need to elevate the women headed households practising family farming to improve living conditions in rural areas. In addition to this, there are no measurement techniques available in India as well as at the international level to measure this concept qualitatively with relevant dimensions. Hence, the scale was developed to facilitate measurement of the latest concept family farming efficiency of women-headed households. The results of measurement will be of immense use to the administrators, academicians/extension personnel and policymakers to formulate the policies and helps in implementation of the programmes more effectively to enhance the contribution of women-headed households practising family farming to enhance food security and sustainable development. With this view, efforts will be made to 
develop and standardized scale to measure the family farming efficiency of women-headed households. The scale developed is a contribution to extension research methodology and the scale can be used by the researchers who desire to undertake research in the area. With this background, the present study has been conceptualized with the objective of developing a scale to measure the family farming efficiency of womenheaded households.

\section{MATERIALS AND METHODS}

The method suggested by Likert (1932), Edwards (1969) and Paul et al. (2013) was followed in developing summated rating scale of family farming efficiency through six stages viz., identification of dimensions, collection of items/statements, editing of the statements relevancy test, item analysis, reliability and validity.

Identification of dimensions and collection of statements: Based on the exhaustive review of the available literature and discussion with experts from related areas the tentative list of six relevant dimensions namely Productivity, Profitability, Employment Generation, Family Labour, Competency in Farm Resource Use \& Socio-Psychological Sensitivity and 154

$$
\begin{gathered}
\text { Relevancy Percentage }=\frac{(\mathrm{MR} \times 5)+(\mathrm{R} \times 4)+(\mathrm{SWR} \times 3)+(\mathrm{LR} \times 2)+(\mathrm{NR} \times 1)}{\text { Maximum Possible score }(\mathrm{i} . \mathrm{e} .330)} \times 100 \\
\text { Relevancy Weightage }=\frac{(\mathrm{MR} \times 5)+(\mathrm{R} \times 4)+(\mathrm{SWR} \times 3)+(\mathrm{LR} \times 2)+(\mathrm{NR} \times 1)}{\text { Maximum Possible score }(\mathrm{i} . \mathrm{e} .330)} \\
\text { Mean Relevancy Score }=\frac{(\mathrm{MR} \times 5)+(\mathrm{R} \times 4)+(\mathrm{SWR} \times 3)+(\mathrm{LR} \times 2)+(\mathrm{NR} \times 1)}{\text { Number of Judges responded }(\mathrm{i} . \mathrm{e} 60)}
\end{gathered}
$$

Accordingly, all the dimensions and statements having 'relevancy percentage' of equal to \& above 80 per cent, 'relevancy weightage' of equal \& above 0.8 and 'mean relevancy score' of above 2.45 for dimensions and above

\begin{tabular}{|c|c|c|c|c|}
\hline Sl. No. & Statements & $\mathrm{RP}$ & RW & MRS \\
\hline \multicolumn{5}{|c|}{ I. Productivity } \\
\hline $1^{*}$ & The huge gap between actual yield and potential yield is observed in our farm. & 92.66 & 0.93 & 4.63 \\
\hline 2 & $\begin{array}{l}\text { All my family members allocate the time and other available resources only for } \\
\text { productive works }\end{array}$ & 81.66 & 0.82 & 4.08 \\
\hline 3 & $\begin{array}{l}\text { One should maintain the soil health, organic matter and fertility through the use } \\
\text { of organic and green manures. }\end{array}$ & 85.66 & 0.86 & 4.28 \\
\hline 4 & $\begin{array}{l}\text { The family headed women should follow Indigenous Technical Knowledge } \\
\text { practices for the economic viability of the farm. }\end{array}$ & 82.00 & 0.82 & 4.10 \\
\hline 5 & $\begin{array}{l}\text { Farm diversification is an important key to enhance productivity in family } \\
\text { farming. }\end{array}$ & 91.00 & 0.91 & 4.55 \\
\hline 6 & Our farm is productive, as it fulfils family requirements such as food, fuel, fodder, & 85.66 & 0.86 & 4.28 \\
\hline
\end{tabular}
4.00 for statements were considered for final selection. Table1. A list of statements with their respective values. the relevancy test.

These listed statements were suitably modified and written as per the suggestions of the judges wherever applicable. statements covering the universe of content in the measurement of family farming efficiency were prepared under different dimension.

Editing of the statements: The statements were edited as per the 14 criteria enunciated by Edwards (1969). As a consequence 60 statements were eliminated and retained 94 statements.

Relevancy analysis: Six dimensions and 94 statements agricultural extension and other related fields working in State Agricultural Universities and Indian Council of Agriculture Research to evaluate the relevancy of each dimension and statement on a three-point continuum total of 60 judges returned the questionnaires. From the data gathered, 'Relevancy Percentage", "Relevancy Weightage" and "Mean Relevancy Score" were worked out for all the six dimensions and 94 statements. Further, the individual dimensions and statements were screened for relevancies using the following formulae; 
Int. J. Agr. Ext. 6(3). 2018. 175-185

\begin{tabular}{|c|c|c|c|c|}
\hline Sl. No. & Statements & $\mathrm{RP}$ & RW & MRS \\
\hline & fibre etc. & & & \\
\hline 7 & Our farm produces more produce than the family requirement. & 83.33 & 0.83 & 4.16 \\
\hline 8 & $\begin{array}{l}\text { Timely identification and control of the pests and diseases in crops/livestock's } \\
\text { are very essential to get more yields. }\end{array}$ & 87.00 & 0.87 & 4.35 \\
\hline 9 & $\begin{array}{l}\text { Appropriate nutrition management ensures animal immunity, growth and } \\
\text { production. }\end{array}$ & 80.66 & 0.81 & 4.03 \\
\hline 10 & Excessive use of inorganic fertilizers reduces the soil productivity & 87.66 & 0.88 & 4.38 \\
\hline 11 & $\begin{array}{l}\text { Family farming provides an opportunity to increase yield per unit area per unit } \\
\text { time by virtue of family labour commitment and concern for their own family } \\
\text { well-being. }\end{array}$ & 90.66 & 0.91 & 4.53 \\
\hline 12 & $\begin{array}{l}\text { The family headed women should not only identify the causes for poor yield but } \\
\text { also manage. }\end{array}$ & 88.33 & 0.88 & 4.41 \\
\hline 13 & $\begin{array}{l}\text { Appropriate nutrition management ensures animal immunity, growth and } \\
\text { production. }\end{array}$ & 92.66 & 0.93 & 4.63 \\
\hline \multicolumn{5}{|c|}{ II. Profitability } \\
\hline $1^{*}$ & One should grow more field crops than commercial crops in the field. & 81.00 & 0.81 & 4.05 \\
\hline 2 & $\begin{array}{l}\text { Family farming provides more profit by reducing the cost of production due to } \\
\text { family labour involvement. }\end{array}$ & 87.33 & 0.87 & 4.36 \\
\hline 3 & Use of organic manures and wastes recycling helps to sustain profitability. & 87.00 & 0.87 & 4.35 \\
\hline 4 & $\begin{array}{l}\text { A family headed women should tie up with the organizations for marketing the } \\
\text { produce to avoid price risk }\end{array}$ & 85.33 & 0.85 & 4.26 \\
\hline 5 & One should always set a target of production and profit on the farm. & 82.00 & 0.82 & 4.10 \\
\hline 6 & $\begin{array}{l}\text { The family headed women should prefer to use minimal off-farm inputs and } \\
\text { maximum on-farm inputs to reduce the cost of production }\end{array}$ & 87.33 & 0.87 & 4.36 \\
\hline $7^{*}$ & $\begin{array}{l}\text { Integration of different farming systems will not increase the profitability of the } \\
\text { farm. }\end{array}$ & 90.66 & 0.91 & 4.53 \\
\hline 8 & $\begin{array}{l}\text { The family headed women makes ensure that the market price offered shouldn't } \\
\text { be less than the cost of production. }\end{array}$ & 88.33 & 0.88 & 4.41 \\
\hline 9 & $\begin{array}{l}\text { ITKs reduce the dependency on external inputs that support farming } \\
\text { endeavours to enhance profitability. }\end{array}$ & 94.33 & 0.94 & 4.71 \\
\hline 10 & Return per rupee of the cost is not dependent on the cost of inputs. & 84.00 & 0.84 & 4.20 \\
\hline \multicolumn{5}{|c|}{ III. Employment Generation } \\
\hline $1^{*}$ & Non - farm income source substitute maximum extent in the family. & 86.33 & 0.86 & 4.31 \\
\hline 2 & $\begin{array}{l}\text { Family members engaged in non-farm activities during slack agriculture seasons } \\
\text { for their earning. }\end{array}$ & 87.00 & 0.87 & 4.35 \\
\hline 3 & Family farming provides assured employment and reduces family poverty. & 90.33 & 0.90 & 4.51 \\
\hline $4^{*}$ & $\begin{array}{l}\text { Employment generated in man-days to women, age holds and children through } \\
\text { family farming can't be equated with men. }\end{array}$ & 94.33 & 0.94 & 4.71 \\
\hline 5 & $\begin{array}{l}\text { The family headed women seek the greater opportunity as they are attracted to } \\
\text { farming as owners /labourers of their farm. }\end{array}$ & 83.66 & 0.84 & 4.18 \\
\hline 6 & $\begin{array}{l}\text { Different farm enterprise of family farming provides enough scope to employ the } \\
\text { family members around the year. }\end{array}$ & 88.00 & 0.88 & 4.40 \\
\hline 7 & Family members feel satisfied to work in their own farms than in urban areas. & 85.33 & 0.85 & 4.26 \\
\hline \multicolumn{5}{|c|}{ IV. Family Labour } \\
\hline 1 & Family members and their farms are linked and co-evolve. & 89.66 & 0.90 & 4.48 \\
\hline $2^{*}$ & Huge difference in the skills of hired labours and family labours. & 82.33 & 0.82 & 4.11 \\
\hline
\end{tabular}


Int. J. Agr. Ext. 6(3). 2018. 175-185

\begin{tabular}{|c|c|c|c|c|}
\hline Sl. No. & Statements & $\mathrm{RP}$ & RW & MRS \\
\hline 3 & Children and age hold will take part during peak seasonal activities. & 84.00 & 0.84 & 4.20 \\
\hline $4 *$ & All family members will work only during leisure time. & 86.66 & 0.87 & 4.33 \\
\hline 5 & Specific farm activities performed by children after school/college hours. & 84.66 & 0.85 & 4.23 \\
\hline $6^{*}$ & $\begin{array}{l}\text { Many times few of my family members spend time and resources for } \\
\text { unproductive works. }\end{array}$ & 89.33 & 0.89 & 4.46 \\
\hline 7 & Family labour promotes effective utilization of available resources. & 84.00 & 0.84 & 4.20 \\
\hline 8 & Hired labour increases the production cost. & 89.33 & 0.89 & 4.46 \\
\hline 9* & $\begin{array}{l}\text { Lack of co-operation among family members is observed frequently while } \\
\text { working on the farm. }\end{array}$ & 81.66 & 0.82 & 4.08 \\
\hline 10 & Family labours can engage themselves in the farm activities for more hours. & 83.00 & 0.83 & 4.15 \\
\hline $11^{*}$ & $\begin{array}{l}\text { My family members simply work because of unemployment rather than to get } \\
\text { high yields. }\end{array}$ & 88.33 & 0.88 & 4.41 \\
\hline 12 & $\begin{array}{l}\text { Cost of production in family farming reduced by the involvement of unpaid } \\
\text { family labours. }\end{array}$ & 80.00 & 0.80 & 4.00 \\
\hline $13^{*}$ & The family headed women can't do hard work for longer hours. & 82.33 & 0.82 & 4.11 \\
\hline 14 & $\begin{array}{l}\text { The family headed women prefer to arrange special occasions for my family } \\
\text { members to complete farm activity on time. }\end{array}$ & 86.66 & 0.87 & 4.33 \\
\hline 15 & $\begin{array}{l}\text { My family members work in other farms on labour sharing basis as and when } \\
\text { needed. }\end{array}$ & 81.00 & 0.81 & 4.05 \\
\hline \multicolumn{5}{|c|}{ V. Competency in Farm Resource Use } \\
\hline 1 & $\begin{array}{l}\text { The successful family headed women should prefer to grow high yielding and } \\
\text { disease resistant varieties in the farm. }\end{array}$ & 88.33 & 0.88 & 4.41 \\
\hline 2 & $\begin{array}{l}\text { Cash can be generated regularly from direct sales of egg, milk and manure in } \\
\text { family farming. }\end{array}$ & 87.67 & 0.88 & 4.38 \\
\hline 3 & One should consciously avoid the use of resources to unproductive works. & 85.33 & 0.85 & 4.26 \\
\hline 4 & $\begin{array}{l}\text { The good family headed women estimate the cost of production and returns } \\
\text { before taking up any enterprise. }\end{array}$ & 87.66 & 0.88 & 4.38 \\
\hline $5^{*}$ & $\begin{array}{l}\text { The family headed women are not serious about safe storage of harvested } \\
\text { produce. }\end{array}$ & 88.33 & 0.88 & 4.41 \\
\hline 6 & $\begin{array}{l}\text { One should plan the crop production after ascertaining the market demands } \\
\text { only. }\end{array}$ & 86.66 & 0.87 & 4.33 \\
\hline 7 & One should follow soil and water conservation techniques on the farm. & 84.66 & 0.85 & 4.23 \\
\hline $8^{*}$ & $\begin{array}{l}\text { The family headed women can't determine and acquire low/no cost } \\
\text { technologies. }\end{array}$ & 81.00 & 0.81 & 4.05 \\
\hline 9 & $\begin{array}{l}\text { One should spend a considerable amount of time in planning and searching for } \\
\text { best resource use practices to get higher yields. }\end{array}$ & 80.33 & 0.80 & 4.01 \\
\hline $10^{*}$ & $\begin{array}{l}\text { The family headed women do not seek any help from professionals or read } \\
\text { literature during pests and disease attack to maintain good crop }\end{array}$ & 87.66 & 0.88 & 4.38 \\
\hline 11 & Livestock supplements crop production and vice versa. & 80.66 & 0.81 & 4.03 \\
\hline 12 & $\begin{array}{l}\text { The progressive family headed women do not buy plant protection chemicals } \\
\text { based on the price only. }\end{array}$ & 84.66 & 0.85 & 4.23 \\
\hline 13 & $\begin{array}{l}\text { The family headed women don't possess sufficient materials to pledge at the } \\
\text { time of emergency. }\end{array}$ & 83.33 & 0.83 & 4.16 \\
\hline $14^{*}$ & $\begin{array}{l}\text { The family headed women do not calculate the fertilizer requirements instead } \\
\text { simply follow the neighbours }\end{array}$ & 80.00 & 0.80 & 4.00 \\
\hline 15 & One should use chemical fertilizers judiciously & 87.66 & 0.88 & 4.38 \\
\hline
\end{tabular}


Int. J. Agr. Ext. 6(3). 2018. 175-185

\begin{tabular}{|c|c|c|c|c|}
\hline Sl. No. & Statements & RP & RW & MRS \\
\hline $16^{*}$ & $\begin{array}{l}\text { Generally, farmers don't take up post-harvest management practices like } \\
\text { processing and value addition. }\end{array}$ & 85.33 & 0.85 & 4.26 \\
\hline 17 & $\begin{array}{l}\text { Multipurpose trees /shrubs in the farm ensure the required quantity of fodder } \\
\text { and green manure. }\end{array}$ & 84.33 & 0.84 & 4.21 \\
\hline $18^{*}$ & $\begin{array}{l}\text { The family headed women are not confident to identify all the pests, diseases } \\
\text { and nutrient deficiency symptoms. }\end{array}$ & 82.00 & 0.82 & 4.10 \\
\hline $19 *$ & Usually, Family headed women does not register to the crop insurance schemes. & 84.00 & 0.84 & 4.20 \\
\hline \multicolumn{5}{|c|}{ VI. Socio-Psychological Sensitivity } \\
\hline 1 & The family headed women shouldn't become upset by the comments of others. & 85.66 & 0.86 & 4.28 \\
\hline $2 *$ & It is difficult to motivate family members to do farm activities. & 87.00 & 0.87 & 4.35 \\
\hline 3 & $\begin{array}{l}\text { The family headed women should not easily be influenced by the suggestions of } \\
\text { others unless it is practically suited to the farm condition }\end{array}$ & 84.66 & 0.85 & 4.23 \\
\hline $4^{*}$ & $\begin{array}{l}\text { Even though family headed women have goals set for the family farm, she finds } \\
\text { problems in setting priorities. }\end{array}$ & 84.33 & 0.84 & 4.21 \\
\hline 5 & One should be firm on the farm decisions are taken. & 83.00 & 0.83 & 4.15 \\
\hline $6^{*}$ & The family headed women very much anxious about market price fluctuations. & 83.66 & 0.84 & 4.18 \\
\hline 7 & $\begin{array}{l}\text { Optimism is the strength for a successful family headed women to move } \\
\text { forward. }\end{array}$ & 82.33 & 0.82 & 4.11 \\
\hline 8 & $\begin{array}{l}\text { The family headed women don't seek moral support very frequently through } \\
\text { elders/ peer group in failures. }\end{array}$ & 87.66 & 0.88 & 4.38 \\
\hline $9 *$ & $\begin{array}{l}\text { A family headed woman is afraid of past experiences in handling the produce } \\
\text { after the harvest. }\end{array}$ & 83.33 & 0.83 & 4.16 \\
\hline
\end{tabular}

*Negative statements, RP: Relevancy Percentage, RW: Relevancy Weightage, MRS: Mean Relevancy Score

Item analysis: Item analysis is an important step while constructing a valid and reliable scale. The judges were asked to indicate their degree of agreement or disagreement on each statement with five-point continuum, namely, Strongly Agree (SA), Agree(A) ,Undecided(UD), Disagree(DA) and Strongly Disagree (SDA) with assigned score of 5, 4, 3, 2 and 1 for positive statements and vice versa for negative statements. The total individual score of judges was calculated by summing up the response score of each statement given by the individual judge

Calculation of ' $\mathbf{t}$ ' values: For carrying out item analysis, two types of scores used, these were the item score, referring to the score of an individual on a particular item and the total score referring to the summation of the item scores of an individual. These scores were used to arrive at the discrimination index. This index indicates the power of an item to discriminate the low effectiveness category from the high effectiveness category of the judges 25 per cent of the subjects with the highest total score is compared with 25 per cent of the lowest total scores. These two groups provided the criterion group for which item analysis was conducted and the critical ratio was calculated by using the following formula;

$t=\frac{\dot{X}_{H}-\dot{X}_{L}}{\sqrt{\frac{\sum X_{H}^{2}-\left(\sum X_{H}\right)^{2} X \sum X_{L}^{2}-\left(\sum X_{L}\right)^{2}}{n(n-1)}}}$

Where,

$\mathrm{XH}=$ The mean score on the given statement of the high group

$\mathrm{XL}=$ The mean score on the given statement of the low group

$\sum \mathrm{x}^{2} \mathrm{H}=$ Sum of squares of the individual score on a given statement for the high group

$\sum x^{2} L=$ Sum of squares of the individual score on a given statement for the low group

$\mathrm{n}=$ Number of respondents in each group

$\mathrm{t}=$ The extent to which a given statement differentiate between the high and low group.

The critical ratio, that is the ' $\mathrm{t}$ ' value which is a measure of the extent to which a given statement differentiates between the high and low groups of judges for each statement was calculated.

After computing the ' $\mathrm{t}$ ' value for all the statements, 66 statements with highest ' $t$ ' value equal to or greater than 
2.048 were finally retained in the scale. Out of 66 statements, 47 are positive and 19 are negative.

Standardization of the scale: The reliability and validity were ascertained for standardization of the scale.

Reliability and Validity of the scale: The developed scale was administered to analyse the family farming efficiency of 30 women headed households in Lingapura village of Bengaluru South Taluk in Bengaluru Rural District, were selected through "Snow Ball Technique".
The split-half method developed by Brown Prophecy in the year 1910 was employed to measure the reliability of the tools.

The reliability coefficient of half test using Karl Pearson's coefficient (r1/2) found 0.8059. The reliability coefficient of tool stood 0.8925 which being higher than the standard value of 0.70 certifies the reliability of the scale. Furthermore, the statistical validity was found 0.94 . Hence, the validity coefficient is most appropriate and suitable for the tool developed.

Table 2. A list of selected statements for final construction with their respective ' $t$ ' values.

\begin{tabular}{|c|c|c|}
\hline Sr. No. & Statements & 't'value \\
\hline \multicolumn{3}{|c|}{ I. Productivity } \\
\hline $1^{*}$ & The huge gap between actual yield and potential yield is observed in our farm. & 3.68 \\
\hline 2 & $\begin{array}{l}\text { All my family members allocate the time and other available resources only for productive } \\
\text { works }\end{array}$ & 5.96 \\
\hline 3 & $\begin{array}{l}\text { One should maintain the soil health, organic matter and fertility through the use of organic } \\
\text { and green manures. }\end{array}$ & 4.43 \\
\hline 4 & $\begin{array}{l}\text { The family headed women should follow Indigenous Technical Knowledge practices for the } \\
\text { economic viability of the farm. }\end{array}$ & 2.70 \\
\hline 5 & Farm diversification is an important key to enhance productivity in family farming. & 4.80 \\
\hline 6 & Our farm is a productive, as it fulfils family requirements such as food, fuel, fodder, fibre etc. & 4.00 \\
\hline 7 & Our farm produces more produce than the family requirement. & 4.17 \\
\hline 8 & $\begin{array}{l}\text { Timely identification and control of the pests and diseases in crops/livestock's are very } \\
\text { essential to get more yields. }\end{array}$ & 3.38 \\
\hline 9 & Appropriate nutrition management ensures animal immunity, growth and production. & 2.92 \\
\hline 10 & Excessive use of inorganic fertilizers reduces the soil productivity & 3.57 \\
\hline 11 & $\begin{array}{l}\text { Family farming provides an opportunity to increase yield per unit area per unit time by } \\
\text { virtue of family labour commitment and concern for their own family well-being. }\end{array}$ & 4.05 \\
\hline 12 & $\begin{array}{l}\text { The family headed women should not only identify the causes for poor yield but also } \\
\text { manage. }\end{array}$ & 3.76 \\
\hline \multicolumn{3}{|c|}{ II. Profitability } \\
\hline $1^{*}$ & One should grow more field crops than commercial crops in the field. & 5.05 \\
\hline 2 & $\begin{array}{l}\text { Family farming provides more profit by reducing the cost of production due to family labour } \\
\text { involvement. }\end{array}$ & 3.25 \\
\hline 3 & Use of organic manures and wastes recycling helps to sustain profitability. & 3.90 \\
\hline 4 & $\begin{array}{l}\text { The family headed women should tie up with the organizations for marketing the product } \\
\text { to avoid price risk }\end{array}$ & 2.55 \\
\hline 5 & One should always set a target of production and profit in the farm. & 5.25 \\
\hline 6 & $\begin{array}{l}\text { The family headed women should prefer to use minimal off-farm inputs and maximum on- } \\
\text { farm inputs to reduce the cost of production }\end{array}$ & 2.96 \\
\hline $7^{*}$ & Integration of different farming systems will not increase the profitability of the farm. & 3.77 \\
\hline 8 & $\begin{array}{l}\text { The family headed women makes ensure that the market price offered shouldn't be less than } \\
\text { the cost of production. }\end{array}$ & 3.70 \\
\hline \multicolumn{3}{|c|}{ III. Employment Generation } \\
\hline $1 *$ & Non - farm income source substitute maximum extent in the family. & 4.84 \\
\hline 2 & Family members engaged in non-farm activities during slack agriculture seasons for their & 2.96 \\
\hline
\end{tabular}


Int. J. Agr. Ext. 6(3). 2018. 175-185

\begin{tabular}{|c|c|c|}
\hline Sr. No. & Statements & 't'value \\
\hline & earning. & \\
\hline 3 & Family farming provides assured employment and reduces family poverty. & 4.58 \\
\hline $4^{*}$ & $\begin{array}{l}\text { Employment generated in man-days to women, age holds and children through family } \\
\text { farming can't be equated with men. }\end{array}$ & 4.30 \\
\hline 5 & $\begin{array}{l}\text { The family headed women seek the greater opportunity as they are attracted to farming as } \\
\text { owners /labourers of their farm. }\end{array}$ & 5.10 \\
\hline 6 & $\begin{array}{l}\text { Different farm enterprise of family farming provides enough scope to employ the family } \\
\text { members around the year. }\end{array}$ & 5.12 \\
\hline \multicolumn{3}{|c|}{ IV. Family Labour } \\
\hline 1 & Family members and their farms are linked and co-evolve. & 2.86 \\
\hline $2^{*}$ & Huge difference in the skills of hired labours and family labours. & 2.32 \\
\hline 3 & Children and age hold will take part during peak seasonal activities. & 4.80 \\
\hline $4^{*}$ & All family members will work only during leisure time. & 3.29 \\
\hline 5 & Specific farm activities performed by children after school/college hours. & 4.18 \\
\hline $6^{*}$ & Many times few of my family members spend time and resources for unproductive works. & 5.74 \\
\hline 7 & Family labour promotes effective utilization of available resources. & 4.39 \\
\hline 8 & Hired labour increases the production cost. & 3.21 \\
\hline 9* & $\begin{array}{l}\text { Lack of co-operation among family members is observed frequently while working on the } \\
\text { farm. }\end{array}$ & 4.58 \\
\hline 10 & Family labours can engage themselves in the farm activities for more hours. & 4.73 \\
\hline $11^{*}$ & My family members simply work because of unemployment rather than to get high yields. & 3.61 \\
\hline 12 & Cost of production in family farming reduced by the involvement of unpaid family labours. & 3.83 \\
\hline $13^{*}$ & The family headed women can't do hard work for longer hours. & 4.52 \\
\hline \multicolumn{3}{|c|}{ V. Competency in Farm Resource Use } \\
\hline 1 & $\begin{array}{l}\text { Successful Family headed women should prefer to grow high yielding and disease resistant } \\
\text { varieties in the farm. }\end{array}$ & 3.67 \\
\hline 2 & Cash can be generated regularly from direct sales of egg, milk and manure in family farming. & 4.75 \\
\hline 3 & One should consciously avoid the use of resources to unproductive works. & 5.96 \\
\hline 4 & $\begin{array}{l}\text { The good family headed women estimate the cost of production and returns before taking } \\
\text { up any enterprise. }\end{array}$ & 5.74 \\
\hline $5^{*}$ & The family headed women are not serious about safe storage of harvested produce. & 3.10 \\
\hline 6 & One should plan the crop production after ascertaining the market demands only. & 4.94 \\
\hline 7 & One should follow soil and water conservation techniques on the farm. & 4.56 \\
\hline $8^{*}$ & The family headed women can't determine and acquire low/no cost technologies. & 2.88 \\
\hline 9 & $\begin{array}{l}\text { One should spend a considerable amount of time in planning and searching for best } \\
\text { resource use practices to get higher yields. }\end{array}$ & 5.80 \\
\hline $10^{*}$ & $\begin{array}{l}\text { The family headed women do not seek any help from professionals or read literature during } \\
\text { pests and disease attack to maintain good crop }\end{array}$ & 4.39 \\
\hline 11 & Livestock supplements crop production and vice versa. & 5.17 \\
\hline 12 & $\begin{array}{l}\text { The progressive family headed women do not buy plant protection chemicals based on the } \\
\text { price only. }\end{array}$ & 4.14 \\
\hline 13 & $\begin{array}{l}\text { The family headed women don't possess sufficient materials to pledge at the time of } \\
\text { emergency. }\end{array}$ & 5.25 \\
\hline $14^{*}$ & $\begin{array}{l}\text { The family headed women do not calculate the fertilizer requirements instead simply follow } \\
\text { the neighbours }\end{array}$ & 4.58 \\
\hline 15 & One should use chemical fertilizers judiciously & 3.70 \\
\hline
\end{tabular}


Int. J. Agr. Ext. 6(3). 2018. 175-185

\begin{tabular}{|c|c|c|}
\hline Sr. No. & Statements & 't'value \\
\hline $16^{*}$ & $\begin{array}{l}\text { Generally, farmers don't take up post-harvest management practices like processing and } \\
\text { value addition. }\end{array}$ & 4.00 \\
\hline 17 & $\begin{array}{l}\text { Multipurpose trees /shrubs in the farm ensure the required quantity of fodder and green } \\
\text { manure. }\end{array}$ & 5.68 \\
\hline $18^{*}$ & $\begin{array}{l}\text { The family headed women are not confident to identify all the pests, diseases and nutrient } \\
\text { deficiency symptoms. }\end{array}$ & 4.29 \\
\hline $19^{*}$ & Usually, Family headed women does not register to the crop insurance schemes. & 3.45 \\
\hline \multicolumn{3}{|c|}{ Socio-Psychological Sensitivity } \\
\hline 1 & The family headed women shouldn't become upset by the comments of others. & 4.05 \\
\hline $2^{*}$ & It is difficult to motivate family members to do farm activities. & 5.17 \\
\hline 3 & $\begin{array}{l}\text { should not easily be influenced by the suggestions of others unless it is practically suited to } \\
\text { the farm condition }\end{array}$ & 3.24 \\
\hline $4^{*}$ & $\begin{array}{l}\text { Even though family headed women have goals set for the family farm, she finds problems in } \\
\text { setting priorities. }\end{array}$ & 3.16 \\
\hline 5 & One should be firm on the farm decisions are taken. & 5.53 \\
\hline $6^{*}$ & The family headed woman is very much anxious about market price fluctuations. & 3.94 \\
\hline 7 & Optimism is the strength for a successful family headed women to move forward. & 3.86 \\
\hline 8 & $\begin{array}{l}\text { The family headed women don't seek moral support very frequently through elders/ peer } \\
\text { group in failures. }\end{array}$ & 3.70 \\
\hline
\end{tabular}

*Negative statements

Administering the scale: The final scale comprises of

Disagree (DA) and Strongly Disagree (SDA) with total 66 statements for measuring the family farming efficiency of women-headed households. assigned score of 5, 4, 3, 2 and 1 for positive statements and vice versa for negative statements. Thus, the The responses were elicited on a five-point continuum, namely, Strongly Agree (SA), Agree (A), Undecided (UD), minimum and maximum score one could get is 66 and 330 respectively.

Table 3. Scale to Measure Family Farming Efficiency of Women Headed Households.

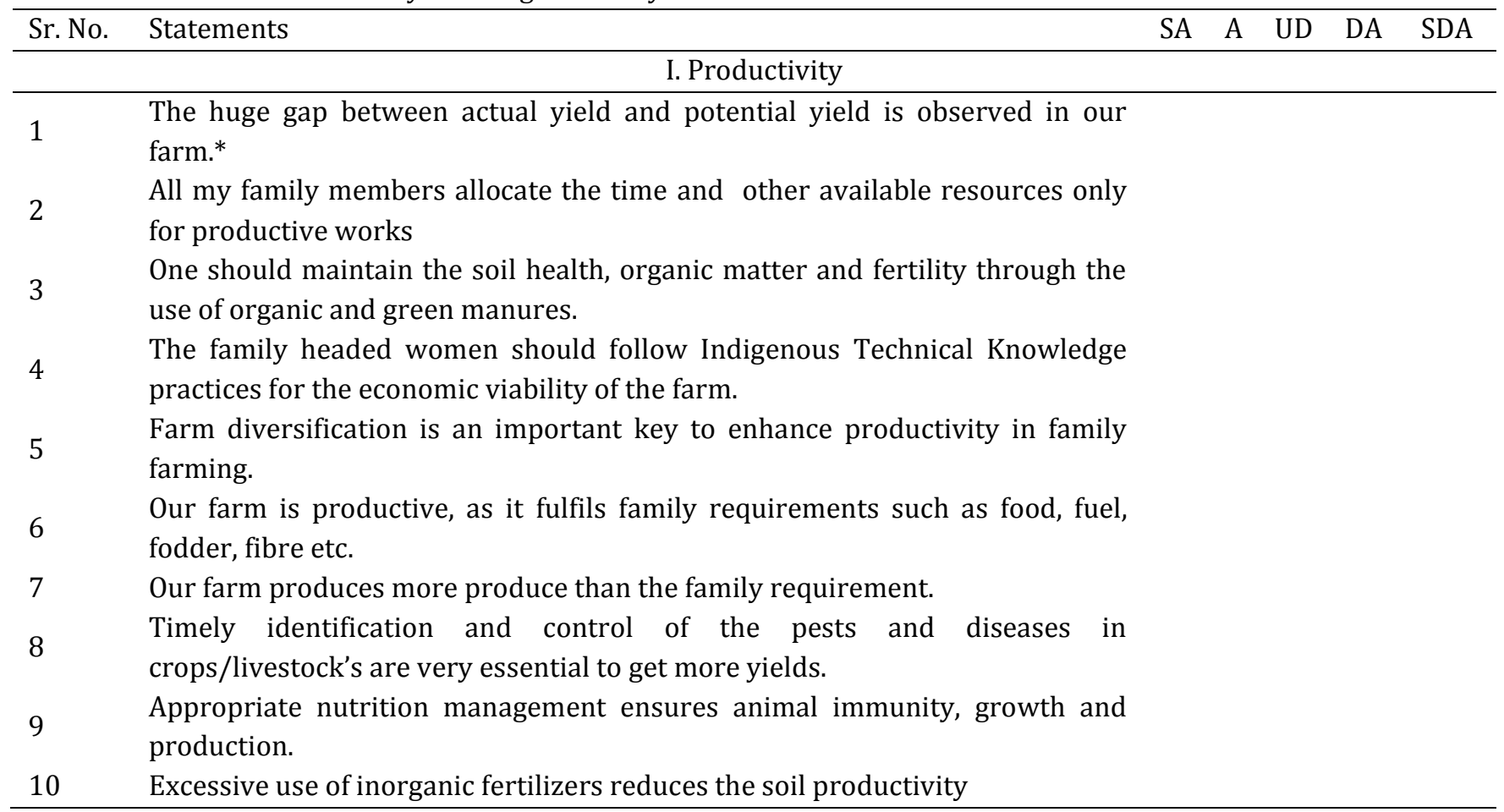




\begin{tabular}{|c|c|}
\hline 11 & $\begin{array}{l}\text { Family farming provides an opportunity to increase yield per unit area per } \\
\text { unit time by virtue of family labour commitment and concern for their own } \\
\text { family well-being. }\end{array}$ \\
\hline 12 & $\begin{array}{l}\text { The family headed women should not only identify the causes for poor yield } \\
\text { but also manage. }\end{array}$ \\
\hline & $\begin{array}{l}\text { II. Profitability } \\
\end{array}$ \\
\hline 1 & One should grow more field crops than commercial crops in the field.* \\
\hline 2 & $\begin{array}{l}\text { Family farming provides more profit by reducing the cost of production due } \\
\text { to family labour involvement. }\end{array}$ \\
\hline 3 & Use of organic manures and wastes recycling helps to sustain profitability. \\
\hline 4 & $\begin{array}{l}\text { A farmer should tie up with the organizations for marketing the product to } \\
\text { avoid price risk }\end{array}$ \\
\hline 5 & One should always set a target of production and profit on the farm. \\
\hline 6 & $\begin{array}{l}\text { The family headed women should prefer to use minimal off-farm inputs and } \\
\text { maximum on-farm inputs to reduce the cost of production }\end{array}$ \\
\hline 7 & $\begin{array}{l}\text { Integration of different farming systems will not increase the profitability of } \\
\text { the farm. }\end{array}$ \\
\hline 8 & $\begin{array}{l}\text { The family headed women makes ensure that the market price offered } \\
\text { shouldn't be less than the cost of production. }\end{array}$ \\
\hline \multicolumn{2}{|r|}{ III. Employment Generation } \\
\hline 1 & Non - farm income source substitute maximum extent in the family. \\
\hline 2 & $\begin{array}{l}\text { Family members engaged in non-farm activities during slack agriculture } \\
\text { seasons for their earning. }\end{array}$ \\
\hline 3 & Family farming provides assured employment and reduces family poverty. \\
\hline 4 & $\begin{array}{l}\text { Employment generated in man-days to women, age holds and children } \\
\text { through family farming can't be equated with men. }\end{array}$ \\
\hline 5 & $\begin{array}{l}\text { The family headed women seek the greater opportunity as they are attracted } \\
\text { to farming as owners / labourers of their farm. }\end{array}$ \\
\hline 6 & $\begin{array}{l}\text { Different farm enterprise of family farming provides enough scope to employ } \\
\text { the family members around the year. }\end{array}$ \\
\hline \multicolumn{2}{|r|}{$\begin{array}{ll}\text { IV. Family Labour } \\
\end{array}$} \\
\hline 1 & Family members and their farms are linked and co-evolve. \\
\hline 2 & Huge difference in the skills of hired labours and family labours. \\
\hline 3 & Children and age hold will take part during peak seasonal activities. \\
\hline 4 & All family members will work only during leisure time. \\
\hline 5 & Specific farm activities performed by children after school/college hours. \\
\hline 6 & $\begin{array}{l}\text { Many times few of my family members spend time and resources for } \\
\text { unproductive works. }\end{array}$ \\
\hline 7 & Family labour promotes effective utilization of available resources. \\
\hline 8 & Hired labour increases the production cost. \\
\hline 9 & $\begin{array}{l}\text { Lack of co-operation among family members is observed frequently while } \\
\text { working on the farm. }\end{array}$ \\
\hline 10 & Family labours can engage themselves in the farm activities for more hours. \\
\hline 11 & $\begin{array}{l}\text { My family members simply work because of unemployment rather than to get } \\
\text { high yields. }\end{array}$ \\
\hline 12 & $\begin{array}{l}\text { Cost of production in family farming reduced by the involvement of unpaid } \\
\text { family labours. }\end{array}$ \\
\hline
\end{tabular}




\begin{tabular}{|c|c|}
\hline 13 & The family headed women can't do hard work for longer hours. \\
\hline \multicolumn{2}{|r|}{ V. Competency in Farm Resource Use } \\
\hline 1 & $\begin{array}{l}\text { The successful family headed women should prefer to grow high yielding and } \\
\text { disease resistant varieties in the farm. }\end{array}$ \\
\hline 2 & $\begin{array}{l}\text { Cash can be generated regularly from direct sales of egg, milk and manure in } \\
\text { family farming. }\end{array}$ \\
\hline 3 & One should consciously avoid the use of resources to unproductive works. \\
\hline 4 & $\begin{array}{l}\text { The good family headed women estimate the cost of production and returns } \\
\text { before taking up any enterprise. }\end{array}$ \\
\hline 5 & $\begin{array}{l}\text { A family headed woman is not serious about safe storage of harvested } \\
\text { produce. }\end{array}$ \\
\hline 6 & $\begin{array}{l}\text { One should plan the crop production after ascertaining the market demands } \\
\text { only. }\end{array}$ \\
\hline 7 & One should follow soil and water conservation techniques on the farm. \\
\hline 8 & $\begin{array}{l}\text { The family headed women can't determine and acquire low/no cost } \\
\text { technologies. }\end{array}$ \\
\hline 9 & $\begin{array}{l}\text { One should spend a considerable amount of time in planning and searching } \\
\text { for best resource use practices to get higher yields. }\end{array}$ \\
\hline 10 & $\begin{array}{l}\text { The family headed women do not seek any help from professionals or read } \\
\text { literature during pests and disease attack to maintain good crop. }\end{array}$ \\
\hline 11 & Livestock supplements crop production and vice versa. \\
\hline 12 & $\begin{array}{l}\text { The progressive family headed women do not buy plant protection chemicals } \\
\text { based on the price only. }\end{array}$ \\
\hline 13 & $\begin{array}{l}\text { The family headed women don't possess sufficient materials to pledge at the } \\
\text { time of emergency. }\end{array}$ \\
\hline 14 & $\begin{array}{l}\text { The family headed women do not calculate the fertilizer requirements instead } \\
\text { simply follow the neighbours. }\end{array}$ \\
\hline 15 & A One should use chemical fertilizers judiciously \\
\hline 16 & $\begin{array}{l}\text { Generally, farmers don't take up post-harvest management practices like } \\
\text { processing and value addition. }\end{array}$ \\
\hline 17 & $\begin{array}{l}\text { Multipurpose trees /shrubs in the farm ensure the required quantity of } \\
\text { fodder and green manure. }\end{array}$ \\
\hline 18 & $\begin{array}{l}\text { The family headed women are not confident to identify all the pests, diseases } \\
\text { and nutrient deficiency symptoms. }\end{array}$ \\
\hline 19 & $\begin{array}{l}\text { Usually, a family headed woman does not register to the crop insurance } \\
\text { schemes. }\end{array}$ \\
\hline \multicolumn{2}{|r|}{$\begin{array}{ll}\text { VI. Socio-Psychological Sensitivity } \\
\end{array}$} \\
\hline 1 & $\begin{array}{l}\text { The family headed women shouldn't become upset by the comments of } \\
\text { others. }\end{array}$ \\
\hline 2 & It is difficult to motivate family members to do farm activities. \\
\hline 3 & $\begin{array}{l}\text { The family headed women should not easily be influenced by the suggestions } \\
\text { of others unless it is practically suited to the farm condition }\end{array}$ \\
\hline 4 & $\begin{array}{l}\text { Even though family headed women have goals set for the family farm, she } \\
\text { finds problems in setting priorities. }\end{array}$ \\
\hline 5 & One should be firm on the farm decisions are taken. \\
\hline 6 & $\begin{array}{l}\text { The family headed women are very much anxious about market price } \\
\text { fluctuations. }\end{array}$ \\
\hline
\end{tabular}




\section{$7 \quad$ Optimism is the strength for a successful family headed women to move forward. \\ 8 The family headed women don't seek moral support very frequently through elders/ peer group in failures.}

*Negative statements (SA-Strongly Agree, A-Agree, UD-Undecided, DA- Disagree, SDA - Strongly Disagree)
CONCLUSION

\section{CONCLUSION}

The reliability and validity of the scale indicate the precision and consistency of the results. Family farming provides scope for efficient utilization of family labour and other farm resources. It can be concluded that the developed scale can be used explicitly to measure the family farming efficiency of Women Headed Households with suitable modifications.

Acknowledgement: I owe my deepest sense of gratitude to $\mathrm{Dr}$ V. L. Madhu Prasad, Professor, Directorate of Extension, University of Agricultural Sciences, Hebbal, Bangalore and Chairman of my advisory committee for his excellent guidance, constant encouragement, and keen interest throughout the course of the investigation. Finally, I wish to thank the family headed women's of Tumakuru District for their cooperation to conduct this research work.

\section{REFERENCES}

Anonymous. (2011).Socio-Economic and Caste Census Report, Press Information Bureau, Government of India, official website. http://secc.gov.in

Edwards, A .L. (1969). Techniques of Attitude Scale Construction.Vakils, Peffer and Simons Pvt. Ltd., 9, Sprott Road, Ballard Estate, Bombay.

Jose -Graziano Da Silva. (2014). Family Farms are key to feeding the world. Rural 21- International Journal of Rural Development, 48(2), 6-7.

Likert, R. (1932). A Technique for the measurement of Attitudes. Archives Psy., 22, 5-55.

Paul, S., Vijayaragavan, P. \& Singh, P. (2013). A Scale to Measure Time Use Efficiency of Agricultural Scientists. Indian Research Journal of Extension Education,13(3),43-46. 